\title{
Factors Affecting the Achievement of Twelve- Year Basic Students in Mathematics and Science in Rwanda
}

\author{
Aimable Sibomana \\ African Center of Excellence for Innovative Teaching and Learning Mathematics \\ and Science (ACEITLMS), \\ University of Rwanda - College of Education (UR-CE), Republic of Rwanda \\ https://orcid.org/0000-0002-9452-9145 \\ Christian Bob Nicol \\ African Center of Excellence for Innovative Teaching and Learning Mathematics \\ and Science (ACEITLMS), \\ University of Rwanda - College of Education (UR-CE), Republic of Rwanda \\ https://orcid.org/0000-0002-5838-0558
}

\author{
Wenceslas Nzabalirwa, Florien Nsanganwimana and Claude Karegeya \\ University of Rwanda - College of Education (UR-CE), Republic of Rwanda \\ https://orcid.org/0000-0002-8299-2001 \\ https://orcid.org/0000-0002-3152-9893 \\ https://orcid.org/0000-0002-5855-7122 \\ John Sentongo \\ Department of Science, Technical and Vocational Education (DSTVE), \\ Makerere University, College of Education and External Studies, Kampala, \\ Republic of Uganda \\ https://orcid.org/0000-0002-8693-2639
}

\begin{abstract}
Although there is an invaluable growth of science and technology across the world, many young people appear to lose interest in Mathematics and science-related subjects due to poor academic achievement caused by different factors. The factors affecting students' achievement in science subjects among sub-Saharan Africa countries,including Rwanda, have been an issue for stakeholders on investigating how to improve the teaching and learning of science in basic education. In this study, a purposive cluster sampling of 261 participants, including 210 students, 23 teachers, seven head teachers, seven Sector Education Inspectors (SEIs), and 14 parents were used. Data were collected through a questionnaire addressed to learners; analyzed using SPSS via descriptive statistics. An interview was
\end{abstract}


conducted with students' representatives, teachers, head teachers,Sector Education Inspectors, and focus group discussion with 14 parents which was analyzed using content analysis. The analysis indicated that key factors of low performance in science subjects include the level of teachers' education; family's economic background; availability of teaching and learning materials; distance covered by learners from home to school; learner's prior knowledge; and level of parents'education and absenteeism of learners. Thus, the above seem to affect the academic achievement of students in the advanced level of Twelve-Year Basic Education in Rwanda. Views about how to improve learning achievements in science such as equipping the laboratories, constructing more $12 \mathrm{YBE}$ schools in various areas to curb the problem of long distances covered by learners to and from school, training teachers on innovative teaching methods were suggested. The results informed that in-service teachers' training and parental involvement should be encouraged to track and sustain learners' learning.

Keywords: basic education; mathematics/science education; academic achievement; innovative teaching methods; Rwandan schools

\section{Introduction}

Science education is a dynamic and relatively broad area. It is seen as the foundation of schooling in many countries, and mathematics and science subjects in higher education are taken as key components for achieving societal needs for ensuring sustainable economic development. In all realms of societal life, young people should be interested to learn mathematics, science,and technology in schools by exploring the world and discover new things (Brock, 2020). The 2030 global agenda for sustainable development aims to have a world with equitable and universal access to quality education at all levels, especially by strengthening science education for the socio-development of some countries, equipping younger generations to develop the capacity-building in all science subjects and the Rwandan national vision. Nonetheless, vision 2020 is now extended to 2050, aims to transform the lives of Rwandans, especially the young citizens into a more economically vibrant and productive population by promoting mathematics and science education. To achieve this goal, all children must get free education as a universal human right according to the 1948 United Nations declaration of human rights. Equally important are the provisions of the convention on the rights of children (Rose \& Alcott, 2015). As a result, the Rwandan government has implemented policies to promote literacy through education for all by instituting basic education systems (among those is TwelveYear Basic Education -12YBE) with more emphasis on science subjects. However, some challenges have been associated with the unsatisfactory level of students' scholastic successes in science subjects (Rwanda Basic Education Board [REB], 2017).

According to Hackling et al. (2001), the attainment of quality science education for the human professional development needs in the sciences is a global concern. For instance, science education researchers in recent years across the nations have revealed unsatisfactory levels of achievement in science disciplines 
(Lerman, 2014). Likewise, a study of the challenges associated with science education in Nigerian secondary schools concluded students' demonstration of fear for science; negative attitudes, and unsatisfactory academic performance (Abulude \& Olawale, 2016). A study conducted in Ghana stated that all facilities could be put in place so that students from the poorest households attend them easily,a contribution to the inclusion and equitable quality education and promotion of lifelong learning opportunities for all (Akyeampong, 2009). Regarding basic education, the experience of Uganda, Tanzania, and Kenya show that the increased enrolment of students atthe primary level increases demands for secondary education that needs the involvement of parents (Oketch \& Rolleston, 2007). In Kenya, an intervention to basic education has been improved by expanding access in general, and students perform better and gain chances to continue to higher levels, but the learning outcomes remain low in public schools, which reduces the benefits of universal education,whereas, in Tanzania, Kalolo (2015) revealed that science teachers should emphasize on what is essential for learners to improve their achievement.

In the Rwandan education system, the Twelve-Year Basic Education (12YBE) comprises of six years of primary school, three years of lower secondary school(ordinary level), and three years of upper secondary (advanced) level. This policy grants every Rwandan child the opportunity and access to education that is free of cost in public day schools (Nizeyimana et al., 2020). The policy of education for all in Rwanda has been put in place to increase the number of students who complete secondary school level and get senior six certificates, but till now, there has been an out cry of the quality of the achievers. World Bank (2016) also stated the low achievement of students in science-related subjects among Sub-Saharan Africa countries, including Rwanda.

The process of teaching and learning mathematics and science should be geared towards learners' scholastic achievement and, when done successfully, leads to the socio-economic development of countries since quality education is an essential requirement for sustainable development of a country. While this brings immeasurable benefits to citizens in the society by adequately preparing the next generation of scientists,stakeholders in education need to provide the very basic needs to alleviate the challenges that these young learners face (Mahdi, 2014). For instance, students need to be educated on the advantages of learning science-related subjects, carry out practical work to gain meaningful learning, acquire appropriate skills and attitudes that will enable them to live and contribute to the development of society (Bugaje, 2013).

In Rwanda, the teaching of mathematics and science still face many challenges, including, for instance, students' misconceptions and negative attitudes towards these subjects. The teaching of science is still dominated by teacher-centered methods as the system still has many unqualified teachers, most of whom are reluctant to embrace the good practices enshrined in the Competence-Based Curriculum (Byusa et al., 2020). With the several efforts such as education for all made by the government to provide the much-needed science education in the country, success will be far-fetched if the learners and teachers alike continue to 
endure the challenges such as school drop out and enrollment retention that have the propensity to degrade the morale and quality of educational gains which can be made in science education among the Twelve-Year Basic Education schools. These concerns are the motivation behind the investigation into the factors that affect the advanced level Twelve-Year Basic Education students.

Based on the realization that the development and general welfare needs of the citizens in Rwanda, the government of Rwanda developed a long term national document plan called Vision 2020,which has been extended to 2050, essentially sought to put Rwanda in a trajectory for economic empowerment and make the country a middle-income country by 2035 and high-income country by 2050 . One of the pillars of this ambitious vision is the provision of affordable basic education and a buoyant economy through strengthening science education. This is to be achieved through a skilled and empowered workforce where education is considered a key factor for success.

The quality of the process of teaching and learning science determines the level of social and transformation in the life of a student and is therefore regarded as an important instrument. In the classroom, the teacher, student, and the curriculum are three keys to the success of the knowledge construction process. In an ideal science classroom, the students are motivated by the self-directed activities in which the teacher is both supportive to learners and knowledgeable about the processes of constructivist learning approaches and the subject matter content (Lerman, 2014). In addition, mathematics and science subjects require a conducive environment with willing students and favorably disposed teachers to achieve learning achievements (Fatokun et al., 2016). Students need hands-on experiences to actively construct knowledge and increase their awareness of the world around them. Practical work and experiments help learners develop the requisite and relevant skills and knowledge needed to make them into useful nation-builders in society (Ebiere Dorgu, 2015). A good foundation of education for all starts with actively involving younger learners in science education. Science -related subjects became a tool for the achievement of their specific targets and channels to find solutions to different issues in their daily lives. Thus, science development is vital for any nation's economic development if science educators create interests and maintain the curiosity of students, which result in the enhancement of productivity and meeting social needs as has been the case in developed and industrializing countries (Lewin, 1992). Thus, a learning institution with equipped, adequate, and relevant instructional resources improves students' academic performance (Likoko et al., 2018).

Students' academic achievement in science refers to students' academic or educational accomplishment (performance outcome) in intellectual domains taught at school, college, and university, and it is represented by scores in an educational system (Bora \& Ahmed, 2018). Academic achievement stimulates the education one gets, which affects their daily life, and is a scheme of learning that produces well-educated persons who can handle matters of concern within their area of study competently. It is to be of quality to catch up students' perspectives and improve their higher academic achievements by strengthening 
science education to increase literacy and capacity-building in science at all levels where students construct their awareness and meaning (Koppenhaver \& Shrader, 2003). Students need to be allowed to engage in practical work since hands-on science in schools provides students opportunities to improve learning and acquire skills and attitudes that qualify them to live and contribute to the development of society (Subedi, 2016). Moreover, students' academic achievement in science is enhanced by effective teaching and scholarship process as the core of education. It depends on fulfilling the goals and objectives of education. It is the powerful instrument of instruction to bring about preferred changes in the students (Ogunkola \& Archer-Bradshaw, 2013). As an indicator, educational achievement is the requirement for individual and societal success; it has long been acknowledged as one of the significant goals of teaching and learning science-related subjects. However, it has been observed that learners who positioned in an equal set of academic circumstances vary in achievement (Areepattamannil et al., 2011).

In developing countries, quality science instruction includes students who are healthy, well-nourished, and are prepared to learn actively with the involvement of their families and communities. That is to say, learning in conducive environments which is safe, protective, and gender-sensitive withadequate resources and facilities, in this situation, generate relevant programs and resources for the achievement of basic skills, particularly in the areas of numeracy and skills for life, health, and nutrition (Cho \& Baek, 2019).These are enhanced in the procedures through which trained teachers apply learnercentered teaching methods in the well-managed classrooms and schools, equipped with competent assessment tools to facilitate learning. Meanwhile, they reduce misconceptions and attain the targeted outcomes that include knowledge, skills, and attitudes, and which are linked to national educational goals for future social-economic development (Lewin, 1992; Sibomana et al., $2020)$.

Constructivism changes today's classrooms into a knowledge-construction place where information is shared and knowledge is constructed by the learner. In science constructivist classrooms, learners are accountable for their learning. At the same time, the teacher plans and organizes different tasks for them (students) and facilites, in case needed, a learning situation that contrasts the conventional lecture. Groups of learning that are formed heterogeneously stimulate students to solve difficulties and challenges in practical situations, whichin turn, leads to the creation of practical solutions by different categories of students (Yassin et al., 2018). The use of internet sources contributes more to constructivist theories in classrooms and homes, since the internet helps in providing tools to experiment to an individual student who can now do different research using the internet and build his/her learning at own pace, interact with diverse materials or an instructor, work on group assignments and share ideas with classmates. Learners can share ideas in a given group of learning, then every learner goes home with tasks to accomplish, then once meet again at school, everyone brings what he/she did and discuss it before recording it as part of the group task (Chaudhary, 2018). 
The learning environment in constructivism encourages the learner to analyze and reflect on the provided information and experiences to result in individualized understanding and isolated learning (Vygotsky, 1980). According to Chaudhary (2018) and Ramsook (2018), educators who apply the constructivism learning theory in their classroom should plan to increase the critical thinking of their learners by allowing them to express their points of view and interact both with their teachers and amongst themselves. Teachers should create classroom situations where hands-on activities are exposed to all learners may also increase social interactions. Therefore, students' role in the constructivism science classroom is about contributing to the activities and the process of learning, discussing new content in group work, hence developing students' critical thinking, problem-solving, and learning on their own rather than listening passively to their educators and following teaching and learning structure.In this regard, the present study aims at investigating factors affecting the learning of students in 12-years basic education schools in Rwanda. The study is built on constructivist theory and the important aspect to document the perceptions among educational stakeholders about their specific views in educational settings. The study informed educational planners and teachers to focus more on learners who mix both school and home activities. Specifically, the study surveyed learners, teachers, educational officials, and parents to learn aboutthe factors affecting learners' learning of mathematics and science in Rwanda.

\section{Methodology}

\subsection{Research Design}

The research was carried out in Nyamasheke District, in the Western province of Rwanda. It focused on eight twelve-years basic education (12YBE) schools with mathematics and science combinations in seven administrative sectors. The sample constituted 261 participants, comprising of 210 students in senior five (S5), 23 mathematics and science teachers, seven head teachers, seven Sector Education Inspectors (SEIs), and 14 parents (from Parent-Teacher Associations, PTA). This study employed a survey designand data were collected using three research instruments; (a) a questionnaire addressed to learners, (b) an interview with students'representatives, teachers, Headteachers, and SEIs, and (c) a focus group discussion with parents. While a cluster random sampling method was used to constitute the sample from eight clusters (eight science combinations among 12YBE schools in the District), interview participants were selected purposively.

\subsection{Research Instruments and Validation}

The questionnaire comprised of seven main sections: personal information, teaching and learning materials within the school, families socio-economic status, teachers' level of education, distance traveled by learners from home to school, rate of students'absenteeism, performance in related science subject (during ordinary level competition while in senior three), and guardians/parents' educational level. The section about teaching and learning materials included seven questions, but in theother sections each had four questions where the participants were requested to tick their responses to the 
questions. Some sections included open-ended questions wherein participants described their opinions about the previous questions. Interview questions were related to learning from key informants about their views on factors that may affect learners' learning and performance in Rwandan schools (see Appendices for different research tools used in this study).

The questionnaire and interview questions were given to experts who helped to check the face validity to critically examine its language clarity, readability, suitability, and lack of ambiguity. They also checked the appropriateness of the statements and the clarity of them to the respondents.To ensure the reliability of the survey questionnaire items, the Cronbach's alpha coefficient was computed in SPSS v.16 (0.80), which according to Fraenkel et al. (2012), indicates an acceptable internal consistency among items.

\subsection{Data Collection and Analysis}

The first round of data was collected in 2015, where students of senior-4 were surveyed, and their Senior-3 national examination (NE) scores were collected from their respective school administrators. At the beginning of 2021, we collected a second round of data where we gathered the Senior-6 NE scores (performed in 2018) of the same students. Thus, we compared the views of various respondents with students' performance over three years. Prior to conducting this study, ethical approval was confirmed since this research involved human beings. Accordingly, all procedures performed in this study were by the ethical standards of the institutional and/or national research committee in Rwanda. Before administering research instruments, each participant was made to sign a consent form for voluntary participation after thorough information was provided on the aim and content of the study, and interviewees were accorded maximum confidentiality by ensuring that handling of said records was restricted only to the researcher. Also, at the end of each conversation, the participants were made to listen to the interview that they gave.

Data from the questionnaire were analyzed using SPSS version 16 and Orgin 8 software, where descriptive statistics were presented in tables and figures.The qualitative data were analyzed using content analysis. We first analyzed data descriptively and then analyzed inferential statistics to reveal the statistical significance of factors affecting the performance of students in the Rwandan context. We triangulated all the information from respondents to present data in a common way, and factors were formulated based on the obtained data.

\section{Data Presentation and Results}

\subsection{Teachers' Qualification Level}

After analyzing the responses given by the teachers as shown by figure 1, the number of unqualified teachers (do not have Bachelor'sdegree or diploma bachelor/diploma (A0/A1) in science with education) out numbered qualified ones (those who have A0 or A1 in science with education). However, many of the unqualified teachers were enrolled in an in-service diploma in the education 
program at data collection. About $25 \%$ of teachers had bachelor's degrees or diplomas in chemistry with education (CE), where 75\% had bachelor's degrees or diplomas in chemistry without education (C). Mathematics teachers were 50\% for each category (mathematics with education and mathematics without education (ME and $\mathrm{M}$ ), while in biology, 57\% had bachelor's degree or diploma of biology with education (BE) and $43 \%$ of biology without education (B).

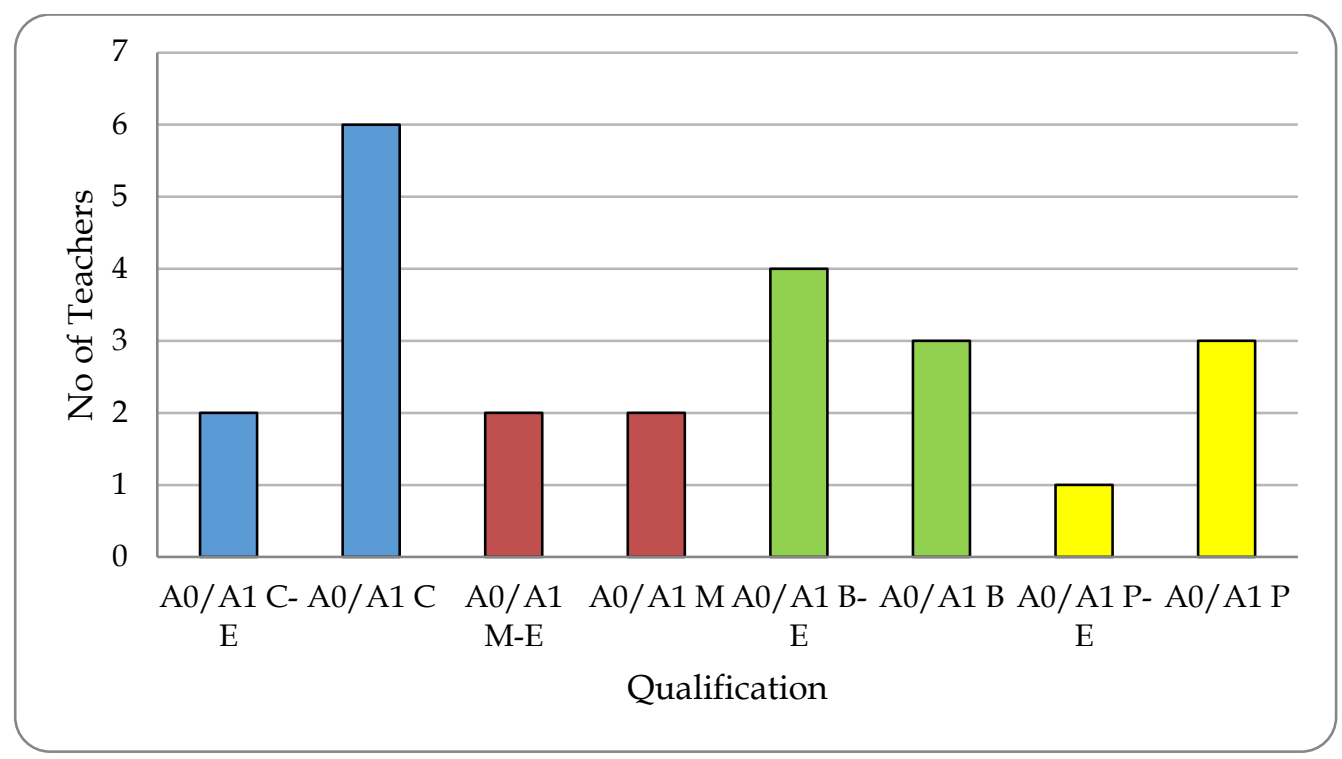

Figure 1: The Level of Teachers' Qualifications.

\section{Note: $\mathrm{A} 1$ is a diploma, $\mathrm{A} 0$ is a bachelor degree}

$25 \%$ of physics teachers had bachelor's degree or diploma in physics with education (PE), and 75\% had bachelor's degree or diploma in physics without an education degree or diploma $(\mathrm{P})$. These findings point to the under-qualification of science teachers, which could hamper the quality of teaching due to unsatisfactory classroom management practices in these schools because they have a major influence on the outcomes of the process of teaching and learning, being in charge of the delivery of type and amount of information that learners can acquire in the classroom. Teacher qualification indicators usually include self-efficacy, knowledge of the content, methodologies of teaching and classroom management, and communication skills.These findings concord with those of Ige and Ogunleye (2016) and Owolabi and Adedayo (2012),who found that teachers' professional qualifications have an effect on academic performance since students are taught by teachers with lower qualifications perform poorly.

\subsection{Families'Economic Background}

It was found that most of the parents' earnings are not sufficient to afford the provision of electricity at home for studies at night,in which $40(19.04 \%)$ had electricity; 38 (18.09\%) used solar energy; none used biogas; $66(31 \%)$ used kerosene, and 66 (31\%) used other sources that were not specified. Learners who come from these homes proceed to the $12 \mathrm{YBE}$ schools as their parents cannot afford to support them through boarding schools known to charge higher tuition and other fees. Invariably, the Twelve-Year Basic Education quality standards 
are deemed to be lower and thus affect learners' academic achievement in mathematics and science subjects. Parents or guardians of about $91(43.3 \%)$ were found to be predominantly farmers (many of them were laborers); 39 (18.6\%) do business; 13 (6.2\%) are teachers; $27(12.8 \%)$ do fishing, and $40(19 \%)$ do not have specified occupations. According to Bora and Ahmed (2018), the levels of the parents socio-economic standing dictates to a large extent the type of school children attend, even those who are in rural areas where teaching and learning facilities are not adequately provided; the parents' status can change the trend that a child can cope with the academic challenges. For talented students who do not need their parents to be literate to influence or change their academic abilities, parents' educational background does not have any relationship with their academic achievement, but the school location can be a predictor of their academic achievement in basic science while in secondary schools.

\subsection{Teaching and Learning Materials}

The sector education inspectors, head teachers, and the teachers themselves indicated difficulties encountered in teaching, among which we mention predominantly lecture, a method that did not address prior knowledge of learners who are, in this case, passive audience. Also, the inadequate facilities like libraries, laboratories, and teaching/learning materials that affected the academic achievement of the 12YBE learners, as instructional materials such as textbooks and science equipment for both teachers and students are key variables at all levels for students' learning and performance which in turn affect learners' motivation and the effectiveness of their lessons as well. The findings are in the same agreement as that of Mupa and Isaac (2015), who discovered that when teachers' instructional materials are limited, learners perform poorly. Similar studies were done in 2014 in Rwanda also outlined this traditional way of teaching and authoritative role of the teacher and following role of learners (Nzeyimana \& Ndihokubwayo, 2019). However, they saw the progress towards reformed teaching of physics (Ndihokubwayo, Uwamahoro, et al., 2020) and effective lesson preparation(Ndihokubwayo, Ndayambaje, et al., 2020) in Rwandan schools.

Busingye and Najjuma (2015) described the relationship between the availability of resources for teaching and learning and the learning gains to be a direct one. Acknowledging this fact, Ndihokubwayo et al. (2019) emphasized the need to enhance the quality of science education by making available adequate supplies of teaching and learning materials because of its immeasurable benefits on secondary and higher-level education.Teaching and learning science by innovative methods direct learners on how to apply a science idea to a variety of phenomena, and students' academic achievement in science related subjects is more enhanced with flexible teachers who are able to adapt the content to learners with different background and abilities in a conducive classroom environment (Gomendio \& OECD Staff, 2017).

\subsection{Distance from Learners' Homes to School and their Absenteeism}

From the findings as detailed in Table 1, the 12YBE schools are few and far; many students walk long distances to and from school. 
Table 1: Distance from Learner's Home to School and their Absenteeism

\begin{tabular}{|c|c|c|c|c|c|c|}
\hline \multirow{2}{*}{$\begin{array}{l}\text { Distance from } \\
\text { learner's home to } \\
\text { school }\end{array}$} & $1-2 \mathrm{~km}$ & $3-4 \mathrm{~km}$ & \multicolumn{2}{|l|}{$5-6 \mathrm{~km}$} & \multicolumn{2}{|c|}{$7 \mathrm{~km}$ and above } \\
\hline & 53 & 38 & 66 & & 53 & \\
\hline \multirow{2}{*}{$\begin{array}{l}\text { Students' } \\
\text { absenteeism }\end{array}$} & $\begin{array}{l}\text { Once a } \\
\text { weak }\end{array}$ & $\begin{array}{l}\text { Twice a } \\
\text { weak }\end{array}$ & $\begin{array}{l}\text { Twice } \\
\text { month }\end{array}$ & $\mathbf{a}$ & $\begin{array}{l}\text { Thrice a } \\
\text { month }\end{array}$ & $\begin{array}{l}\text { They } \\
\text { always } \\
\text { attend }\end{array}$ \\
\hline & 52 & 27 & 66 & & 27 & 38 \\
\hline
\end{tabular}

This effect directly renders students' exhaussion for any follow-up reading at home,a factor that could affect their academic achievement. Lower scholastic achievement can be attributed to distances covered by students to and from school. $25.23 \%$ of students travel 1 to $2 \mathrm{~km}$ from home to school; $18.09 \%$ travel 3 to $4 \mathrm{~km} ; 31.4 \%$ travel 5 to $6 \mathrm{~km}$, and $25.23 \%$ travel $7 \mathrm{~km}$ and above. In addition, students who find themselves in these situations tend to do homework assignments alone rather than in the companionship of their classmates. Baliyan and Khama (2020), in their research, also confirmed that the distance traveled by learners to school and back home affects their academic achievement. Table 1 also showed the absenteeism of students from school and was also found to greatly deter learners' progress and performance in school as $24.7 \%$ of students admitted to being absent from school at least once a week; $12.8 \%$ twice a week; $31.4 \%$ twice a month; and $12.8 \%$ thrice a month. These findings represent an alarming rate of absenteeism, which has the propensity to affect academic performance negatively.

\subsection{Learners' Prior Knowledge and Achievement}

In analyzing students' scores at the ordinary level examination during the academic year 2015 and their achievement at the completion of senior six in 2018 (seeTable 2) among seven schools that have science and mathematics combinations, we found that $6.19 \%$ of student had passed in division I (aggregates that are between eight and 32); 6.19\% students in division II (33-45 aggregates); $31.4 \%$ students in division III (46-52 aggregates); and 56.19\% students had passed in division IV (53-69 aggregates). However, none could pass in division $\mathrm{V}$ which indicates the failure (70 and above) in the ordinary level examination in which the lower the aggregate, the greater the achievement. This is unlike the senior six examinations where aggregates range from nine to 73 (which is the contrary at the completion of senior six where aggregates started from nine to 73 ).

Table 2: Learners' Prior Knowledge (their performance in senior three/the academic year 2015) versus Learners' Achievement at the Completion of Senior Six/the Academic Year 2018 (in aggregates)

\begin{tabular}{ccccccc}
$\begin{array}{c}\text { Prior } \\
\text { knowledge }\end{array}$ & $\begin{array}{c}\text { Division } \\
\text { I (8-32) }\end{array}$ & $\begin{array}{c}\text { Division } \\
\text { II (33-45) }\end{array}$ & $\begin{array}{c}\text { Division } \\
\text { III (46-52) }\end{array}$ & $\begin{array}{c}\text { Division } \\
\text { IV (53-69) }\end{array}$ & $\begin{array}{c}\text { Div V (70 } \\
\text { and above) }\end{array}$ & \\
\cline { 2 - 7 } & 13 & 13 & 66 & 118 & 0 & \\
\hline \multirow{3}{*}{ Achievement } & Division & Division & Division & Division & Div V & Dropped \\
& I (57-73) & II (41-56) & III (25-40) & IV (9-24) & (Unclassified) & out \\
\cline { 2 - 7 } & 3 & 4 & 46 & 143 & 6 & 8 \\
\hline
\end{tabular}


At the completion of senior six, three students $(1.43 \%)$ passed in the first division (57-73 aggregates); four $(1.90 \%)$ in the second division; $46(21.90 \%)$ in third division; $143(68.09 \%)$ in the fourth division; six $(2.86 \%)$ in the firth division (failed). The achievement of students after secondary school showed that more than $70.96 \%$ of students succeeded with low marks, and only a reduced number of students experience the necessary success $(25.23 \%)$ that could allow them to continue in higher learning institutions, while $3.81 \%$ dropped out within the journey.This implies that there is either a low predictive validity of the tests, or the students' academic achievement had dropped. Whichever is true, it negatively affects learners' academic achievement. This finding is not different from that of Won (2010) in which if students' prior knowledge has gaps and insufficiencies, it may not adequately support new knowledge.

A constructivist science classroom may offer a diversity of activities to challenge students to accept individual differences, use concrete learning experiences (Ramsook, 2018). In a constructivist science classroom, teachers/ facilitators motivate students to discover and think positively about the content progressively from simple to complex topics, and assist students' work to reflect on what they have been doing and provide constructive feedback (Shute, 2008).

\subsection{Parents' Educational Level}

This study found that parents acknowledge their responsibility to guide and assist their children with their school work. However, the problem remains that they are not literate enough to offer meaningful academic assistance to their children. Consequently,this affects learners' academic achievement because there is no positive academic influence of their parents on the children.Figure 2 shows parents' educational qualifications.

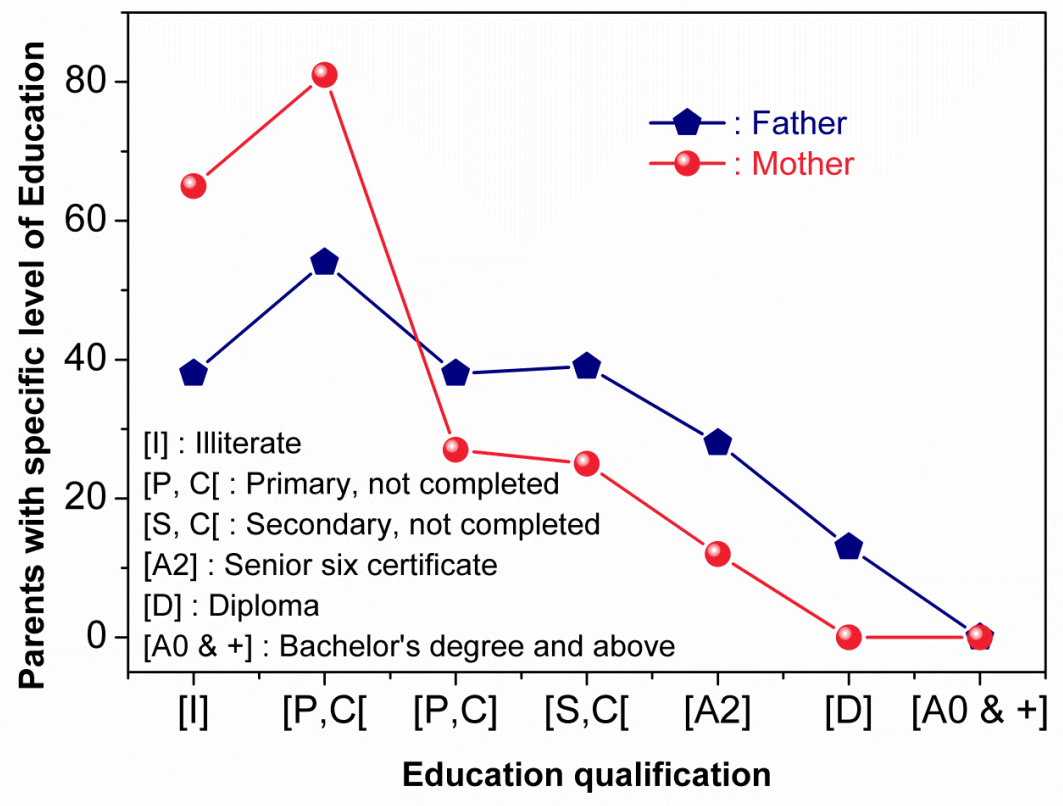

Figure 2: Family Educational Background

Similarly, parents and relatives were revealed as key guides to assist learners in their achievement in Rwanda(Ukobizaba et al., 2019). Also, uneducated parents 
and/or guardians are observed to be isolated from school decision-making processes with irregular follow-up of their education progress, which impacts their achievement (Brown et al., 2020).

\section{Findings and Discussion}

\subsection{Relationship between Independent and Dependent Variables}

As shown in Table 3, a positive significant relationship existed between teachers' qualification $(\mathrm{r}=.168, p<.05)$, distance traveled from learners' home to school $(\mathrm{r}=.735, p<.000)$, students' family economic background $(\mathrm{r}=.568, p<.000)$, type of energy used $(\mathrm{r}=.709, p<.000)$, learner's prior knowledge (performance in S3NE $(\mathrm{r}=.714, p<.000)$, absenteeism of students $(\mathrm{r}=.742, p<.000)$, education level of the father $(\mathrm{r}=.685, p<.000)$ and education level of the mother $(\mathrm{r}=.735, p<.000)$.

Table 3: Relationship between Independent and Dependent Variables

\begin{tabular}{lcc}
\hline Independent Variables & $\mathrm{R}$ & $p$-value \\
\hline Teacher qualification & .168 & $.015^{*}$ \\
\hline Distance home-school & .735 & $.000^{*}$ \\
\hline Family's economic background & .568 & $.000^{*}$ \\
\hline Type of energy used & .709 & $.000^{*}$ \\
\hline Learner's prior knowledge & .714 & $.000^{*}$ \\
\hline Absenteeism of students & .742 & $.000^{*}$ \\
\hline Education Level of Father & .685 & $.000^{*}$ \\
\hline Education Level of Mother & .735 & $.000^{*}$ \\
\hline
\end{tabular}

Dependent variable: Students'Performance in SSciencein S6NE ${ }^{*} \mathrm{p}<.05$

Table 4 showed that a linear positive and significant relationship existed between the predictor variables (teacher qualification, distance home-school, family's economic background, type of energy used, learner's prior knowledge, absenteeism of students, education level of father and education level of mother) and performance among the senior six secondary school students. The table indicated that the multiple $\mathrm{R}$ was 0.857, which implies a high positive relationship among the predictor variables and the criterion variable (students' performance in science in S6NE). As such, 73.5\% (as indicated by $\mathrm{R}$ square of 0.735) of the variation observed in the performance in science among senior six secondary school students was explained by the combination of the predictor variables.

Table 4: Summary of Regression Analysis of the Predictor Variables on the Students Achievement (Criterion Variable)

\begin{tabular}{cccccccc}
\hline Multiple R & $\mathbf{. 8 5 7}$ & $\begin{array}{c}\text { Source of } \\
\text { variance }\end{array}$ & SS & Df & $\begin{array}{c}\text { Mean } \\
\text { Square }\end{array}$ & Fc & $\begin{array}{c}\text { P- } \\
\text { value }\end{array}$ \\
\hline $\mathrm{R}^{2}$ & .735 & Regression & 87.43 & 8 & 10.928 & 69.58 & 0.000 \\
Adjusted R & .724 & Residual & 31.57 & 201 & .157 & & \\
Standard & .396 & Total & 118.99 & 209 & & & \\
Error & & & & & & & \\
\hline
\end{tabular}


Moreover, the analysis of variance for the multiple regression data yielded an Fratio of 69.583, which was significant at $p<0.05$. This implies that the combination of the eight predictor variables (qualification, distance traveled from learners' home to school, students' family economic background, type of energy used, learner's prior knowledge (performance in S3NE), absenteeism of students, education level of father and education level of mother) have a significant influence on performance in science among senior six secondary school students in Nyamasheke district.

\subsection{Key Determinants of Students' Performance in S6NE}

This study also established the key determinants of students' performance in science in S6NE in the Nyamasheke district. To this end, the regression analysis was computed. Table 5 summarises the findings.

Table 5: Determinants of Students' Performance in S6NE

\begin{tabular}{lcc}
\hline Independent Variables & $\begin{array}{c}\text { Standardized Beta } \\
(\boldsymbol{\beta}) \text { weight }\end{array}$ & P-value \\
\hline Teacher qualification & .111 & $.003^{*}$ \\
\hline $\begin{array}{l}\text { Distance traveled from learners' home to } \\
\text { school }\end{array}$ & .251 & .096 \\
\hline Family's economic background & .655 & $.000^{*}$ \\
\hline Type of energy used & .104 & .473 \\
\hline $\begin{array}{l}\text { Learner's prior knowledge (Performance in } \\
\text { S3NE) }\end{array}$ & .456 & $.000^{*}$ \\
\hline Absenteeism of students & .106 & .668 \\
\hline Education Level of Father & .116 & .224 \\
\hline Education Level of Mother $\quad .885$ & $.000^{*}$ \\
\hline \multicolumn{1}{c}{ Dependent variable: Students'Performance in S6NE, ${ }^{*} p<.05$} \\
\end{tabular}

As it can be seen in table 5 , teacher qualification is a statistically significant predictor of students' performance in science in S6NE. It indicates that there is a significant difference between the performance of students who were taught by qualified teachers and that of students who were taught by less qualified teachers, as shown by the standardized beta coefficient of the students' teachers qualification status, which is statistically significant $(\beta=.111, p<0.05)$. The $\beta$ value indicates that students who are taught by qualified teachers perform better than students taught science by unqualified teachers, as shown by the positive coefficient of .111.

Moreover, table 5 revealed that family background status is another key predictor of students' performance. The table clearly showed that a statistically significant difference exists between the performance of students from high economic families and the performance of students from low economic families, as shown by the standardized $\beta$ coefficient of the parental employment status $(\beta=.655, p<0.05)$. The latter indicates that for every one unit of increase in the family economy, student's performance decreases by 0.655.Furthermore, another key predictor of students' performance in S6NE is the student's prior performance in ordinary level examinations (S3NE). The value of the 
standardized $\beta(\beta=.456, p<0.05)$ tells that one unit increases student's prior performance in S3NE and improves his/her performance in S6NE by .456.

Finally, there is a statistically significant difference between the performance of students whose mothers are educated and the performance of students whose mothers are not educated, as shown by the standardized beta coefficient of the students'mother's education level, which was statistically significant $(\beta=.885$, $p<0.05)$. Students whose mothers are educated were seen to perform better than their counterparts whose mothers are not educated. Therefore, an increase in the level of education of the students' mothers is expected to increase the student's performance by .885 .

\section{Conclusion}

From the findings of this research, we observed that factors which affect the Twelve -Year Basic Education advanced level students' achievement in science are: the level of teachers' qualification, family economic backgrounds, teaching and learning materials, distance from learners' homes to schools, learners' prior knowledge, levels of parents' education and students' absenteeism. Over $60 \%$ of all science teachers of 12 YBE schools in Nyamasheke District, Rwanda, have no teaching credentials. A big number of unqualified teachers is in chemistry and physics subjects with more than $70 \%$.As a result of fewer schools, many students cover long distances to schools, which is the reason for most of the absenteeism with only $18.9 \%$ of students were present throughout the term. The pattern of students' scores in the ordinary level exams, which was at a low level, could not be improved at the completion of senior six-level three years afterward, which could have been partially due to a decline in the quality of teaching services or factors that affect it. These factors which affect the students' academic achievement in mathematics and science may be the same in developing countries where a small number of schools, learners attend school irregularly due to some works they are engaged in to support their families and with parents who cannot support their learners' learning effectively are among the constains that render learners' practices. This study adds value to the existing knowledge since it highlights major factors that hinder the achievement of students in mathematics and science subjects among Twelve-Year Basic Education (12YBE) students in Rwanda; it also gives insight intoschools' administration; Parent-Teacher Associations (PTA), and to educate stakeholders to play a community role for the improvement of students' achievement in science subjects.

\section{Recommendation}

In-service teachers who are untrained and unqualified should be encouraged to undertake an in-service teacher training through a soft loan scheme. Teachers should also use the appropriate methods such as cooperative learning and peer teaching, peer instruction when teaching by putting more emphasis on practical works in science to lead the students to make more discoveries on their own. School administrations should also facilitate regular refresher workshops to let teachers help each other in different domains to improve the teaching and learning of mathematics and science.In addition, the parent-teacher associations 
need to collaborate with the school's disciplinary committee to make sure that lateness and students missing out on lessons are minimized. The findings from the present study should be interpreted with caution due to a limitation in the research design used. The respondents explain their own experience and opinion subjectively according to their understandings. Their status as day school students might have influenced them to perform poorly for a while and loose motivation to learn science-related subjects. This is why it is highly recommended that further studies may be conducted on the same sample applying an innovative teaching method by catering/ addressing some of the listed factors to improve learners' academic achievement.

\section{Acknowledgements}

The authors appreciate the financial support from the African Center of Excellence for Innovative Teaching and Learning Mathematics and Science (ACEITLMS) of the University of Rwanda - College of education (UR-CE).

\section{References}

Abulude, \& Olawale, F. (2016). Teacher and students' attitude towards chemistry in selected secondary schools in Akure Nigeria. In Advancing Education In The Caribbean And Africa, (pp. 93-105). Science and education development institute.

Akyeampong, K. (2009). Revisiting free compulsory universal basic education (FCUBE) in Ghana. Comparative Education, 45(2), 175-195. https://doi.org/10.1080/03050060902920534

Areepattamannil, S., Freeman, J. G., \& Klinger, D. A. (2011). Intrinsic motivation, extrinsic motivation, and academic achievement among Indian adolescents in Canada and India. Social Psychology of Education, 14(3), 427-439. https://doi.org/10.1007/s11218-011-9155-1

Baliyan, S. P., \& Khama, D. (2020). How distance to school and study hours after school influence students' performance in mathematics and English: A comparative analysis. Journal of Education and E-Learning Research, 7(2), 209-217. https://doi.org/10.20448/JOURNAL.509.2020.72.209.217

Bora, A., \& Ahmed, S. (2018). Parents' socio-economic status and pupils' mathematics achievement: Stepwise multiple regression analysis approach. Online Submission, 4(11), 316-322. https:// doi.org/10.13140/RG.2.2.28384.53760/1

Brock, W. H. (2020). Science education. In Companion to the history of modern cience, 49(0), 946-959. Routledge. https://doi.org/10.4324/9781003070818-70

Brown, M., McNamara, G., Cinkir, S., Fadar, J., Figueiredo, M., Vanhoof, J., O'Hara, J., Skerritt, C., O'Brien, S., Kurum, G., Ramalho, H., \& Rocha, J. (2020). Exploring parent and student engagement in school self-evaluation in four European countries. European Educational Research Journal, 20(2), 159-175. https://doi.org/10.1177/1474904120961203

Bugaje, B. M. (2013). Qualitative chemistry education: The role of the teacher. IOSR Journal of Applied Chemistry, 4 (5), 10-14.https:/ / doi.org/10.9790/5736-0451014

Busingye, J. D., \& Najjuma, R. (2015). Do learning and teaching materials influence learning outcomes amidst high enrolments? Lessons from Uganda's Universal primary education. Africa Education Review, 12(1), 109-126. https://doi.org/10.1080/18146627.2015.1036572

Byusa, E., Kampire, E., \& Mwesigye, A. R. (2020). Analysis of teaching techniques and scheme of work in teaching chemistry in Rwandan secondary schools. EURASIA Journal of Mathematics, Science and Technology Education, 16(6), 1-9. 
https://doi.org/10.29333/ejmste/7833

Chaudhary, B. (2018). The role of ICT in promoting constructivism. International Journal of Technical Research \& Science, $3(1) . \quad 1-4$. https://doi.org/10.30780/ijtrs.v3.i1.2018.001

Cho, J., \& Baek, W. (2019). Identifying factors affecting the quality of teaching in basic science education: Physics, biological sciences, mathematics, and chemistry. Sustainability (Switzerland), 11(14).39-58. https://doi.org/10.3390/su11143958

Ebiere Dorgu, T. (2015). Different teaching methods: A panacea for effective curriculum implementation in the classroom. International Journal of Secondary Education, 3(6), 77-87. https://doi.org/10.11648/j.ijsedu.s.2015030601.13

Fatokun, K. V. F., Egya, S. O., \& Uzoechi, B. C. (2016). Effect of game instructional approach on chemistry students' achievement and retention in periodicity. European Journal of Research and Reflection in Educational Sciences, 4(7), 29-40.

Fraenkel, J. R., Wallen, N. E., \& Hyun, H. H. (2012). How to design and evaluate research in education (8th ed.). San Francisco State University: Mc Graw Hill.

Mahdi, G. J. (2014). Student attitudes towards chemistry: An examination of choices and preferences. American Journal of Educational Research, 2(6), 351-356. https://doi.org/10.12691/education-2-6-3

Gomendio, M., \& OECD Staff. (2017). Empowering and enabling teachers to improve equity and outcomes for all. International Summit on the Teaching Profession. Paris: OECD Publishing.https://doi.org/10.1787/9789264273238-en

Hackling, M. W., Goodrum, D., \& Rennie, L. (2001). The state of science in Australian secondary schools. Australian Science Teachers Journal, 47(4), 617.https://ro.ecu.edu.au/ecuworks/4682/

Ige, O. M., \& Ogunleye, A. W. (2016). Causes and remedies to low academic performance of students in public secondary schools : A study of Ijero local government area of Ekiti state. Research on Humanities and Social Sciences, 6(15), 66-71.

Kalolo, J. F. (2015). The quest for quality science education experiences in Tanzanian secondary schools. Journal of Studies in Education, 5(2), 22-39. https://doi.org/10.5296/jse.v5i2.7146

Koppenhaver, G. D., \& Shrader, C. B. (2003). Structuring the classroom for performance: Cooperative learning with instructor-assigned teams. Decision Sciences Journal of Innovative Education, 1(1), 1-21. https:/ / doi.org/10.1111/1540-5915.00002

Lerman, Z. M. (2014). The challenges for chemistry education in Africa.African Journal of Chemical Education,4(2), 80-90.

Lewin, K. M. (1992). Science education in developing countries: Issues and perspectives for planners.International Institute for Educational Planning. UNESCO

Likoko, S., Mutsotso, S., \& Nasongo, J. (2018). Adequacy of instructional materials and physical facilities and their effect on the quality of teacher preparation in colleges in Bungoma county. International Journal of Science and Research,2(1),403-408. http://erepository.kibu.ac.ke/handle/123456789/1039

Mupa, P., \& Isaac., T. C. (2015). Factors contributing to ineffective teaching and learning in primary schools: Why are schools in decadence? Journal of Education and Practice, 6(19), 125-132.

Ndihokubwayo, K., Uwamahoro, J., \& Ndayambaje, I. (2019). An assessment of the impact of improvised versus conventional laboratory equipment on students' performance in thermal expansion. African Journal of Educational Studies in Mathematics and Sciences, 15(1), 135-140. https:/ / doi.org/10.4314/ajesms.v15i1.11

Ndihokubwayo,K., Ndayambaje, I., \& Uwamahoro, J. (2020). Analysis of lesson plans from Rwandan physics teachers. International Journal of Learning, Teaching and 
Educational Research, 19(12), 1-29. https://doi.org/10.26803/ijlter.19.12.1

Ndihokubwayo, K., Uwamahoro, J., \& Ndayambaje, I. (2020). Implementation of the competence-based learning in Rwandan physics classrooms: First assessment based on the reformed teaching observation protocol. EURASIA Journal of Mathematics, Science and Technology Education, 16(9), 1-8. https://doi.org/https://doi.org/10.29333/ejmste/8395

Nizeyimana, G., Nzabalirwa, W., Mukingambeho, D., \& Nkiliye, I. (2020). Hindrances to Quality of Basic Education in Rwanda. Rwandan Journal of Education, 5(1), 1-14.

Nzeyimana, J. C., \& Ndihokubwayo, K. (2019). Teachers' role and learners' responsibility in teaching and learning science and elementary technology in Rwanda. African Journal of Educational Studies in Mathematics and Sciences, 15(2), 1-16.

Ogunkola, B. J., \& Archer-Bradshaw, R. E. (2013). Teacher Qqality indicators as predictors of instructional assessment practices in science classrooms in secondary schools in Barbados. Research in Science Education, 43(1), 3-31. https://doi.org/10.1007/s11165-011-9242-5

Oketch, M., \& Rolleston, C. (2007). Chapter 5 policies on free primary and secondary education in east Africa: Retrospect and prospect.Review of Research in Education,31 (1). https:// doi.org/10.3102/0091732X07300046131

Owolabi, O. T., \& Adedayo, J. O. (2012). Effect of teacher's qualification on the performance of senior secondary school physics students: Implication on technology in Nigeria. English Language Teaching, 5(6), 72-76. https://doi.org/10.5539/elt.v5n6p72

Ramsook, L. (2018). Cooperative learning as a constructivist strategy in tertiary education. International Journal of Education and Research, 6(1).,149-160.

Rose, P., \& Alcott, B. (2015). How can education systems become equitable by 2030?. DFID think pieces-Learning and equity. http:/ / heart-resources. org.

REB. (2017). Teacher training manual - Reflections on teaching practice and focus on assessment (3rd Phase). Rwanda Ministry of Education.

Shute, V. J. (2008). Focus on formative feedback. Review of Educational Research, 78(1), 153-189. https://doi.org/10.3102/0034654307313795

Sibomana, A., Karegeya, C., \& Sentongo, J. (2020). Students' conceptual understanding of organic chemistry and classroom implications in the Rwandan perspectives: A literature review. African Journal of Educational Studies in Mathematics and Sciences, 16(2), 13-32.https://www.ajol.info/index.php/ajesms/article/view/204184

Subedi, D. (2016). Explanatory sequential mixed method design as the third research community of knowledge claim. American Journal of Educational Research, 4(7), 570577. https://doi.org/10.12691/education-4-7-10

Vygotsky, L. S. (1980). Mind in society: The development of higher psychological processes. Harvard university press.

Ukobizaba, F., Ndihokubwayo, K., Mukuka, A., \& Uwamahoro, J. (2019). Insights of teachers and students on mathematics teaching and learning in selected Rwandan secondary schools. African Journal of Educational Studies in Mathematics and Sciences, 15(2), 93-107. https://www.ajol.info/index.php/ajesms/article/view/192088

World bank. (2016). An overview of the progressive science initiative and progressive mathematics initiative (PSI-PMI) and its implementation in the Gambia. World Bank.

Won, S. Y. (2010). How does students' prior knowledge affect their learning?In How learning works: Seven research-based principles for smart teaching (pp. 10-39).

Yassin, A. A., Razak, N. A., \& Maasum, N. R. M. (2018). Cooperative learning: General and theoretical background. Advances in Social Sciences Research Journal, 5(8), 642654. https://doi.org/10.14738/assrj.58.5116 


\section{Appendices}

\section{Appendix A: Questionnaire for senior five students in mathematics and science combinations}

\section{Instructions}

You have been selected to participate in this research, which focuses on factors affecting the advanced level of Twelve-Year Basic Education (12YBE) students' achievements in mathematics and Science in Rwanda. Your inputs are very important for meeting the objectives of this research.

Please, write the letter of your preferable answer in the curled brackets [ ] located in each question. Furthermore, you are kindly requested to give some short explanation where allocated.

\section{A . Identification}

1. Name of the School:

2. Date of interview (Date/Month/Year):

B. Personal information

1. What is your age in complete years?

2. What is your sex?
a) Male
[ ]
b) Female

3. Combination
a) $\mathrm{MCB}$
b) $\mathrm{PCM}$
c) $\mathrm{PCB}$
d) BCG

\section{Science related subject preference and facilities}

1. Do you like mathematics and science subjects?

a) Very much?

b) Not much?<smiles>C1CC[AlH]C1</smiles>

c) I don't like any mathematics and Science related subject [ ]

2. What are the reasons for your answer in (1)?

a) I love mathematics and science teachers

c) Mathematics and science-related subjects are important in my future carrier

d) I hate mathematics and science teachers

e) Mathematics and science subjects are difficult

f) I don't know the importance of mathematics and science subjects in my future life More reasons if any

3. Does the school have a science laboratory?

a) Yes

b) No<smiles></smiles>

c) I don't know [ ] 
4. A. If yes, how many times have you entered the laboratory as a class to do some experiments or to observe a demonstration?
a) Less than five times
b) Five or more than five times
[ ]
c) More than ten times
d) I have never entered the school laboratory for studies?

4. B. Science laboratories have the following facilities

a) All necessary chemicals (acids, bases, litmus paper, test tube and beaker) [ ]

b) Only a few chemicals and not enough beakers

c) Laboratory has no facilities

5. Does the school has laboratories for other subjects?
a) Yes
[ ]
b) No
[ ]
c) I don't know [ ]

If Yes, tick $[\sqrt{ }]$ all the laboratories which the school has
a) Mathematics laboratory [ ]
b) Physics laboratory
c) Biology laboratory
d) Computer laboratory

Others please mention:

5. Do you have your own science books?

a) Yes [ ]

b) No [ ]

6. If yes, How many/per subject?
a) One
b) Less than five
c) More than five
d) More than ten
e) Not applicable

[ ]
[ ]
[ ]
[ ]
[ ]

7. From where did you get those books?

a) Received from my guardians/parents, friends or relatives [ ]

b) I bought with my own money

c) Not applicable

Other sources, please explain.

8. Does the school provide science books to students?
a) Yes [ ]
b) No [ ]

\section{Distance traveled by learners}

1. What distance do you walk from your home to school?
a) $1-2 \mathrm{~km}$ (1-24 minutes)
b) $3-4 \mathrm{~km}$ (25- 48 minutes)
c) $5-6 \mathrm{~km}$ (49- $1 \mathrm{~h} 10$ minutes) [ ] 
d) 7-above (more than 1 hour and 10 minutes) [ ]

\section{E. Absenteeism}

1. How often do you miss attending class for different reasons?

a) Once a week

b) Twice a weak

c) Twice a month

d) Thrice a month

e) Other information:

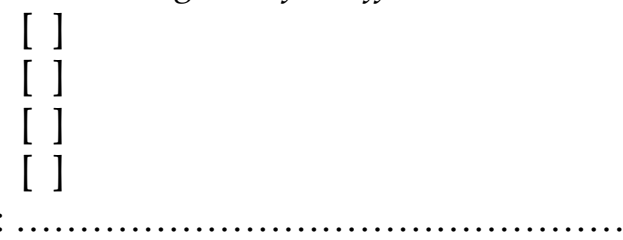

\section{F. Performances in mathematics and science-related subjects}

1. What are the performances in the following science subjects at your school/ refer to divisions you got in National examinations (S3NE- the academic year 2015) and in senior six (S6NE-academic year 2018)

i. Chemistry

ii. Biology

iii. Physics

iv. Mathematics

S3NE
a) Worse (division V) [ ]
b) Bad (division IV) [ ]
c) Good (division III) [ ]
d) Better (division II) [ ]
e) Best (division I) [ ]
(f) I don't know

\section{G. Reason behind}

1. What are the reasons for your answer in C (1)?
S6NE

Worse (division V) [ ]

Bad (division IV) [ ]

Good (division III) [ ]

Better (division II) [ ]

Best (division I) [ ]

I don't know

2. What do you think are the reasons that cause such kind of performance?

Tick $[\sqrt{ }]$ all the reasons you agree with

a) There is no enough and qualified mathematics and science teachers in our schools [ ]

b) There are few science facilities such as textbooks, chemicals, and other science materials in our schools [ ]

c) Poor awareness on the importance of science subjects in students future life or careers [ ]

d) Science subjects are difficult [ ]

Other please explain,

3. What do you suggest should be done to improve performance in science subjects? 


\section{H. Motivations}

1. Are there any gifts given to the best students in mathematics and science subjects at your school?

a) Yes [ ]

b) No [ ]

If yes, please mention them

\section{Guardians'/Parent's information; support/encouragement}

1. What is the education level of your parents/guardians?

a) Never went to school :

b) Went to primary school but never completed:

c) Completed primary school:

d) Went to secondary school but never completed:

e) Has a S6 certificate:

f) Has a Diploma:

g) Has a Bachelor's Degree:

h) Did a postgraduate course (Master/DEA, PhD):

i) Others:

Mother [ ]; Father [ ] Mother [ ]; Father [ ] Mother [ ]; Father [ ] Mother [ ]; Father [ ] Mother [ ]; Father [ ] Mother [ ]; Father [ ] Mother [ ]; Father [ ] Mother [ ]; Father [ ] Mother [ ]; Father [ ]

2. What is the occupation of your parents/guardians?
a) Farming [ ]
b) Business [ ]
c) Teaching [ ]
d) Fishing [ ]
e) Public/Private service [ ]
f) Others:

3. What type of energy used in your parents/guardians 'house for lighting?
a) Electricity [ ]
b) Solar panel [ ]
c) Biogas
d) Kerosene [ ]
e) Any other source of energy, please indicate:

4. Do your parents/care givers encourage you to perform well in science subjects?
a) Yes [ ]
b) No [ ]
If yes, please mention them

\section{J. Constraints}

1. Please mention any constraints which are facing the learning of science subjects 


\section{Appendix B: Interview for students}

1. What are factors/problems do you think to affect 12YBE students' achievement in science subjects?

2. What are the effects of these factors on the process of teaching and learning science subjects among 12 YBE schools?

3. During which period and for what reasons do you not attend class regularly?

\section{Appendix C: Interview for teachers}

0)School name:...

1) Indicate the level of your qualification:
a) $A_{2}$ teaching [ ]
e) $\mathrm{A}_{2}$ non-teaching
b) $\mathrm{A}_{1}$ teaching [ ]
f) $A_{1}$ non teaching
c) $A_{0}$ teaching [ ]
g) Anon teaching
d)) Masters
h) Other:

2) According to you, what are factors that affect $12 \mathrm{YBE}$ students' achievement in science subjects?

3) What are the effects of these factors on the process of teaching and learning science subjects among $12 \mathrm{YBE}$ schools?

4) As a teacher, what strategies do you propose to enhance students' achievement in science subjects among 12YBE schools?

5) As a teacher, what do you think could be the role of parents in improving students' achievement in science subjects among $12 \mathrm{YBE}$ schools?

6) How can the lack of a science laboratory slow down the achievement of students in science subjects among $12 \mathrm{YBE}$ schools?

7) How can absenteeism of learners affect $12 Y B E$ students' achievement in science subjects?

Appendix D: Information to be given by the school secretary or Director of Studies (DOS)

Section A: General information on the school

1) Type of the school: a) $12 \mathrm{YBE}$

b) Boarding school

2) Location of your school: Rural

Urban

Section B: Information on staff and students

3) What is the number of your staff by gender?

a) Teaching staff: Male:

Female:

Sub-total:

b) Administrative staff: Male:

Sub-total:

Female:

c) Support staff: Male:

Female:....

Sub-total: 
4) What is the number of teaching staff with the following qualifications in the advanced level of your school?
a) $\mathrm{S} 6$ certificate-
b) Diploma--------
c) Bachelor's Degree-
d) Master's Degree-
e) Any other, please mention-

5) What is the number of teachers with the following types of degrees?
a) Bed-
b) BA with Education
c) BSc with Education
d) B.A----------
e) $\mathrm{BSc}$
f) Med
g) M.A, MSc,MBA, and others-

6) What is the number of your student population according to their combinations and gender?
a) BCG: Male:.....
b) MCB: Male:....
c) PCB: Male:....
d) PCM: Male:....
Female:......
Sub-total :.......
Female:.....

\section{Sub-total}
Female
Female:

\section{Appendix E: Interview guide for Headteachers}

1) According to you what are factors that affect 12YBE students' achievement in Science?

2) What are the effects of these factors on the process of teaching and learning science subjects among 12YBE schools?

3) As a Headteacher, what are strategies do you propose to enhance $12 \mathrm{YBE}$ students' achievement in Science?

4) How can absenteeism of students affect students' achievement in science subjects among $12 \mathrm{YBE}$ ?

5) What could be the contribution of parents to enhance 12YBE students' achievement in science subjects?

6) How can the distance traveled by students from their home to school affect 12YBE students' achievement in science subjects?

\section{Appendix F: Interview guide for SEIs}

1) According to you, what are factors affect $12 \mathrm{YBE}$ students' achievement in science subjects?

2) What are the effects of these factors on the process of teaching and learning science among $12 \mathrm{YBE}$ schools?

3) What strategies do you propose to enhance 12YBE students' achievement in science subjects?

4) How can absenteeism of students influence 12YBE students' achievement in science subjects?

5) What could be the contribution of parents to enhance 12YBE students' achievement in science subjects? 
6) How can the distance traveled by students from their home to school affect $12 \mathrm{YBE}$ students' achievement in science subjects?

\section{Appendix G: Interview guide for parents}

1) What problems do your children in the advanced level of $12 \mathrm{YBE}$ face while learning science subjects? [ $\mathrm{Ni}$ ibihebibazoabanabanyu biga mu cyicirocyakabiricy'amashuriyisumbuyeya 12YBE bahuranabyo mu masomoyasiyansi?]

2) What are the effects of these factors/ problems on the process of teaching and learning science subjects in the Advanced level of 12YBE? [Ibyobibazobifiteizihengaruka mu masomoyabo?]

3) What could be your contribution to resolve those problems? [Uruharerwanyurwagombyekubauruhe mu gukemuraibyobibazo?]

4) Do you assist your children while doing their science homework? [Mujyamukurikirana/mufashaabanabanyu mu gihebarigukoraimikoroy'amasomoyasiyansiigihebari mu rugo?]

5) What strategies do you propose to enhance $12 \mathrm{YBE}$ students' achievement in science subjects? [Ni

izihenamamwatangakugirangohazamurweiremery'imyigishirizen'imyigir ey'amasomoyasiyansi muri gahunday'uburezibw'ibanzebw'imyakacumin'ibiri?]

6) How can the distance traveled by students from their home to school affect 12 YBE students' achievement in science subjects? [Ni guteurugendoumunyeshuriakora ava mu rugoiwaboajyakuishuri, rushoborakugiraingarukakumyigire ye $n^{\prime}$ imitsindire $m u$ masomoyasiyansi?] 